\title{
Employer Attractiveness: Comparative Perceptions of Undergraduate and Postgraduate Students
}

\author{
Bhadra J.H. Arachchige \\ Senior Lecturer (Grade I) \\ Department of HRM \\ University of Sri Jayewardenepura \\ and \\ Alan Robertson \\ Head of Education \\ Saegis Campus, Sri Lanka
}

\begin{abstract}
In many countries the employer brand is fast becoming an integral facet of an organisation's resources aimed at attracting and retaining the employees best able to contribute to the successful attainment of its vision and goals. This study expands on an earlier survey in Sri Lanka of the employer attributes most important in attracting job-seekers, drawing on the perceptions of Sri Lankan undergraduate Business/Commerce students in their final semester before graduation and comparing those findings with the results of a similar survey of MBA students who have had varying periods of employment experience. While the findings reveal a difference in the degree to which the two sample groups are attracted or otherwise to a range of employer attributes, they nonetheless have similar perceptions as to which of these are most and least preferred. A close alignment between the dimensions of attractiveness relevant to each group is also identified. The implications of these findings for HRM managers are discussed.
\end{abstract}

Key Words: Employer Brand, Perception

\section{Introduction}

The employer brand is a wholesome picture created within employees and respective future employeees' mind of the package of psychological, economic, and functional benefits provided by employment and identified with a particular employer (Throne 2004,Wilden, Gudergen and Lings, 2010). Cultivating an employer brand is one method used by firms to recruit and retain the most sought after employees, namely those who they believe will perpetuate their brand success and secure ongoing profitability. This process is anchored on the belief that the outcomes will give practicing firms a competitive edge.

There are a number of reasons why the need to recruit and retain staff has become such an important issue for organizations. Foremost is the increasing level of recognition of the importance of human capital, the skills, experience and knowledge of employees, as sources of value to the firm and its shareholders. The value of companies is now much more centred on intellectual rather than hard assets. In 2007, The Economist reported that intangible assets now represent around $70 \%$ of the value of companies in the Standard \& Poor's 500 index compared to $20 \%$ in 1980 (Rosethorn, 2009). Underlying this interest in employer branding is the fact that the demand for skilled, specialist, value-adding employees is likely to increase 
dramatically in the short to medium term, especially because of the rapid growth of new technologies and the rise of emergent economies, particular in Asia. At the same time, demographic and social factors have already reduced the supply of skilled labour. While in OECD countries ten active workers supported four older, inactive people in 2000, this will increase to seven inactive people by the year 2050. This skill shortage is likely to create a $30 \%$ decrease in productivity over that period if it is not addressed (Taylor, 2005).

The importance of maximizing the ability to attract the best employees is further strengthened by the fact that within the field of marketing there is a strong awareness of the impact of employees on business effectiveness, particularly with respect to brand strategy and management. The ongoing personal contact of employees with consumers gives them a great deal of influence over the way in which consumers view the company. Employees also have the ability to help build strong brands, particularly within the service sector.

Recent research indicates that employer branding is a current management priority in leading companies, and increasing in importance (Van Mossevelde, 2010). There are five reasons for this:

a) Shortage of skilled labour: despite the economic downturn of 2008-11 and higher unemployment levels in many countries, the need for top talent and the right employees still exists.

b) More with less: During the economic downturn there is pressure for organizations to cut costs and increase productivity, making the need for the right people in the right jobs even more critical.

c) Growth and profitability: hiring and retaining the best possible employee talent is essential for growth and to maintain a competitive edge.

d) Popularity: research into recruitment reveals that employees of all levels want to work for companies with good reputations. Unpopularity as an employer can have a domino effect on the product and corporate brands.

e) Strength: being an attractive employer increases the power of organizations to retain employees, often irrespective of salary levels.

It could be easy to view employer branding as a fad which lacks relevance during a recession. With unemployment levels touching double digit percentages the imperative for organizations to market their unique qualities to prospective employees may be considered both wasteful of time and money (Sheppard, 2010). However, even though economies have experienced one of the worst recessions in living memory in the period leading up to the present day, the Chartered Institute of Personnel and Development claims that $68 \%$ of employers still experienced recruitment difficulties in 2010 (Tweedy, 2011).

This paper addresses the Sri Lankan perception of employer attractiveness, an extending study previously conducted on finding out preferred employer attributes of graduating business degree students (Arachchige and Robertson, 2011) through the use of a modified version of the Australian-developed Employer Attractiveness scale (EmpAt) (Berthon, Ewing and Hah, 2005). In addition, factors that may influence the 
job seekers' perceptions such as reputation variables, personal characteristics and academic background were considered.

As the majority of job seekers are experienced workers, unlike the graduating university students, it was felt that the study should be extended to gain an insight into the dimensions of attractiveness which draw this group towards preferred employers. This is not to say that the perceptions of the graduating students are irrelevant as they are, in most cases, actively looking for employment. However, it must be acknowledged that they are representative of only one sector of job applicants and their perceptions will be influenced by age, education, social relationships and types of work sought (Wells, 1993).

As a focus for this study therefore, it is proposed to build on the foundation of data obtained in our initial study and compare it with the perceptions of experienced employers in relation to the factors that would attract them to a preferred employer.

\section{Background - Evolution of the Employer Brand}

During the 1990s it was increasingly recognized that attracting and retaining the best employees for an organization was becoming not only important to brand development and maintenance but also more difficult to achieve, partly due to the demographic challenges faced by the major western economies as well as the highmaintenance, high expectation and high self-interest attitude of the Generation Y talent segment (those born between 1977 and 1995). Rosethorn (2009, p.8) has summed it up as follows:

"Job security is a thing of the past as companies grow and shrink, hire and fire. 'Job consumers' in turn have more choice and less affiliation to a single employer. They vote with their feet, more freely and happily than before, and loyalty to a corporate purpose is much harder to create and sustain. Research shows again and again that employees feel more loyalty to their colleagues than to the organization, and these priorities are particularly prevalent in the attitudes of Generation $Y$."

During the mid-1990s a new organizational branding concept emerged in response to these trends - the employer brand. All organizations that employ people have an employer brand whether they realize it or not. However, since the introduction of the term "employer branding" in 1996, firms from a diverse range of industry sectors have formally defined and are strategically managing their image in the eyes of current and prospective employees in order to gain the benefits that the process is purported to produce. The term "employer brand" can be defined formally as "the package of functional, economic and psychological benefits provided by employment, and identified with the employing company" (Ambler and Barrow, 1996) while "the sum of a company's efforts to communicate to existing and prospective staff that it is a desirable place to work"'(Lloyd, 2002) describes the employer branding process. Although employer branding strategies may have been around for some time previously, it was the emerging struggle to attract talented workers that encouraged professional firms in the US in particular to look more carefully at what distinguished them as employers and then to think of their employment proposition as a brand 
similar to their corporate or customer brands (Carrington, 2007). Firms tend to be expending considerable resources on employer branding campaigns, an indication that they find it a valuable practice (Backhaus and Tikoo, 2004)

Employer branding shares a theoretical foundation with consumer and corporate branding and impacts many of the same stakeholders (employees, customers, shareholders). Unlike consumer and corporate branding, however, the target market of the employer brand is the current and prospective employees of the employing firm. As such it is generally seen as falling within the province of the human resource management (HR) function of an organization although there is an increasing trend for this role to be managed by multi-disciplinary teams composed of marketing, communications and HR personnel (Minchington, 2009).

\section{Employer Attractiveness}

Employer attractiveness can be defined as "the envisioned benefits that a potential employee sees in working for a specific organization" (Berthon, Ewing and Hah, 2005, p.156). In an emerging "war for talent" (Chambers et al, 1998) many employers have identified the need to develop and present an image which will serve to attract both the number and quality of job applicants required to ensure the highest levels of productivity from their organizational workforce.

\section{Figure 1: Association between employer brand and employer attractiveness}

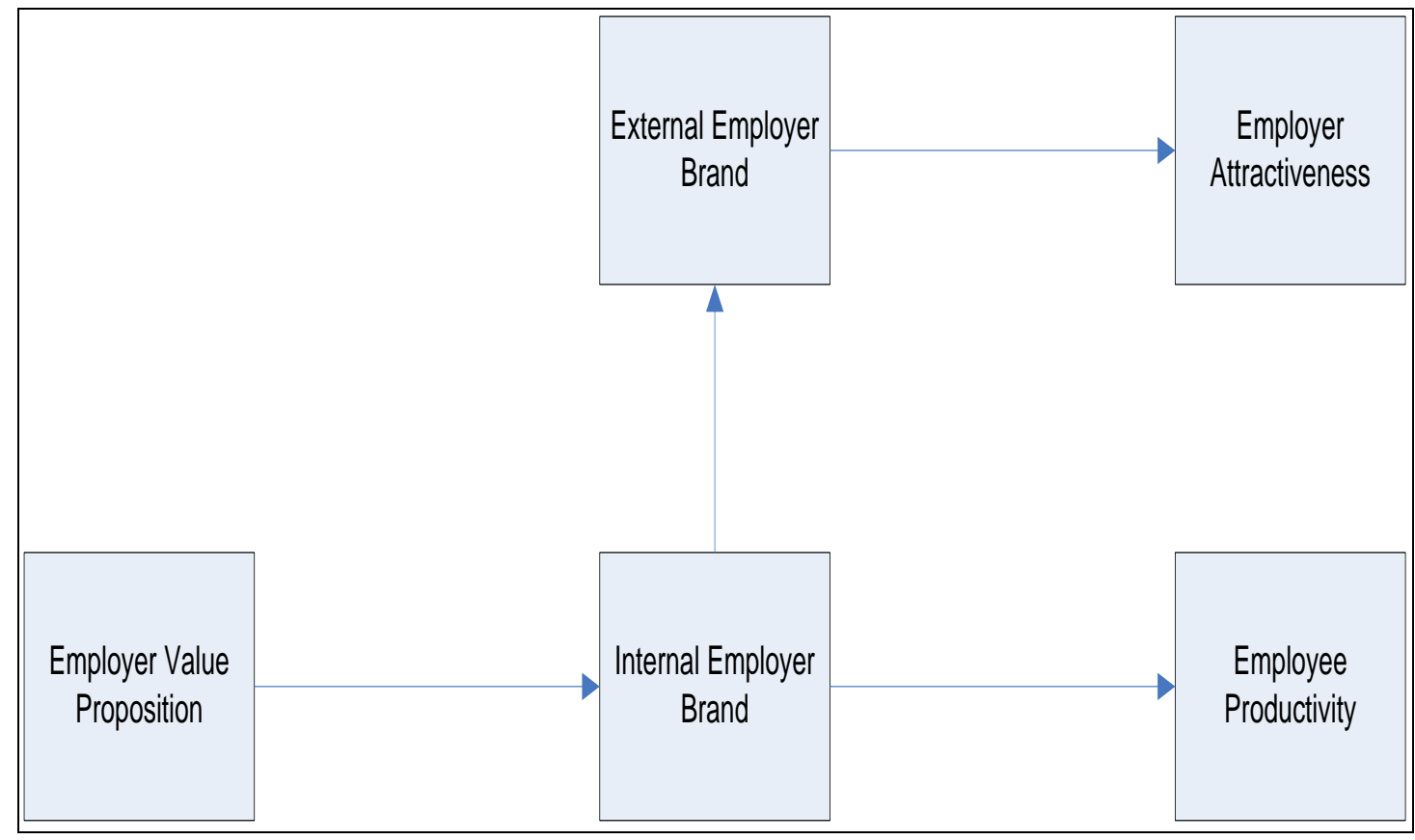

Figure 1 illustrates the two major facets of employer branding, namely an external brand image aimed at attracting potential employees, and an internal brand image relevant to employee satisfaction and loyalty, retention, productivity and support for the product brand. Employer attractiveness, as the diagram indicates, is the outcome of the external branding process and, as such, represents a significant component of the value of the brand, its equity. The greater an employer's attractiveness the stronger the organisation's employer brand equity (Berthon et al, 2005). In many 
countries it has become a popular practice, particularly for business magazines, to produce regular rankings of employers in terms of their standing as an "employer of choice". High ratings in such instruments can be a great advantage for organizations. Collins and Stevens (2002) examined the impact of publicity, sponsorship, word-ofmouth endorsements and advertising on the employer brand as a stimulus to recruitment. Their findings indicate that publicity is a significant factor, most likely because it comes from a source outside the organization itself. Companies that are able to create publicity about themselves may receive the greatest return for their investment in other early recruitment activities.

For organizations in general, and particularly for those involved in the human resource management, marketing and publicity functions, there is undoubtedly a need for a greater understanding and awareness of the role of employer attractiveness in the recruitment function. The aim of this study therefore is to explore this area further.

Towards this end our research will be directed to a comparison between graduating students and experienced employees of:

\section{The attributes of preferred employers}

There is concern that concentrating on students in surveys of job applicants can be of limited value in that they represent only a small percentage of job applicants and have little knowledge of employment experience. It has therefore been claimed that they are more likely than experienced employees to be influenced by recruiters and recruitment practices in evaluating an employer's attributes and therefore less aware of job and organizational attributes (Rynes, Heneman and Schwab, 1980). As a result we therefore propose that:

Hypothesis 1: There is a significant difference between graduating students and experienced employees in the degree to which employer attributes attract them to an employer.

\section{The key factors which influence the perception of preferred employers}

Studies by Maxwell and Knox (2009) and Lievens (2007) indicated that current and potential employees tend to perceive an organisation's brand in different ways. Similarly, Cable and Graham (2000) demonstrated that the reputation perceptions of senior undergraduate student job seekers were based on different factors than those used by corporate executives. Once again we see that this is an area which requires further understanding in relation to the employer branding aspect of organizational recruitment. Accordingly we posit the following hypothesis:

Hypothesis 2: There is a significant difference between graduating students and experienced employees in the most-and least-preferred attributes which attract them to an employer.

\section{The dimensions of employer attractiveness}

In their original paper introducing the employer branding concept, Ambler and Barrow (1996) identified three dimensions that defined employer identity, namely psychological, functional and economic. Berthon, Ewing and Hah (2005), using the EmpAt scale, extended this perspective to five dimensions: social, development, application, interest and economic. 
On the basis of our previous study we identified eight dimensions of employer attractiveness which we believe are of value to human resource management practitioners in the recruitment of graduate students to their organisations:Job structure,Social commitment, Social environment, Relationships, Personal growth, Organisational Dynamism, Enjoyment, and Corporate environment. Relating these to the highest and lowest preferred employer attributes of the Sri Lankan graduating Business students it was seen that the Personal Growth and Relationships factors were most important while the Corporate Environment and Enjoyment were of least interest.

In relation to the previously mentioned studies which indicate the likelihood of significant differences in the perception of employer attractiveness between graduating students and experienced current employees, the third objective of this study was to examine the possibility of similar differences in the dimensions relevant to each group. Accordingly we suggest that:

Hypothesis 3: There is a significant difference between graduating students and experienced employees in the dimensions of attractiveness to a preferred employer.

\section{Research Method}

Data for our previous study of final year undergraduate Business student perceptions of employer attractiveness was gathered through a questionnaire completed by a convenience sample of 221 respondents. Part A of the questionnaire contained 32 items to measure aspects of employer attractiveness, 25 of which were drawn from the EmpAt scale developed by Berthon, Ewing and Hah (2005) on the basis of a study conducted in Australia. An examination of other literature on the topic suggested that there were additional organizational factors that could impact on attractiveness. These included profitability, publicity, size, type of product or service (Cable and Graham, 2000), the quality of the management, honesty and fairness and personal respect. As a result, seven additional items were added. It should be noted that the terminology of some questions was changed to make them more easily understood by Sri Lankans, as often they may come from a background where English is not normally used.

Part B of the questionnaire sought personal details of the respondents such as gender, course GPA and educational background in order to identify factors which may impact on their perception of attractiveness.

As a mechanism for comparing perceptions of employer attractiveness between graduating students and experienced employees a further questionnaire was developed and administered to a convenience sample of $87 \mathrm{MBA}$ students. Part A of the questionnaire contained the same 32 items as used in the undergraduate survey while Part B focused on personal details of respondents such as age, gender, academic and professional qualifications, current employment, length of work experience and type of industry in which they work. The MBA students had an average of 6.2 years in employment, ranged in age from below 24 to over 55 years, had first degrees from a wide range of academic disciplines and were engaged in a variety of occupations.

Data analysis for testing the first hypothesis was drawn from the mean scores of the 308 respondents on the 32 items in Part A of the questionnaire which measured the 
responses to each of the items reflecting items of employer attractiveness. These were calculated for the undergraduate students and the MBA students. The independent samples $t$-Test was used to ascertain whether there was a statistical difference between the mean scores of the graduating students and the MBA students.

Each of the groups rated their attractiveness to an employer on the 32 items in the modified EmpAt scale. The preferences of the two groups were identified and the correlation coefficient determined in order to draw conclusions related to Hypothesis 2 .

Factor analysis was used to determine from the 32-item adaptation of the EmpAt scale the significant dimensions of employer attractiveness for the two groups. The means of the dimensions were calculated and analysed using the independent samples $t$-Test. In all instances the data was analysed using SPSS.

\section{Discussion of Findings}

\section{Effect of employment experience upon perceptions of attractiveness}

Table 1: Results of independent samples $t$-Test Group Statistics

\begin{tabular}{|l|l|r|r|r|r|}
\hline & EmpEx & \multicolumn{1}{|c|}{$\mathrm{N}$} & \multicolumn{1}{c|}{ Mean } & Std. Deviation & Std. Error Mean \\
\hline $\begin{array}{l}\text { Mean32Ite } \\
\text { ms }\end{array}$ & Undergraduate & 221 & 5.7089 & .53148 & .03575 \\
\hline & MBA Students & 87 & 5.9015 & .48207 & .05168 \\
\hline
\end{tabular}

Independent Samples Test

\begin{tabular}{|c|c|c|c|c|c|c|c|c|c|c|}
\hline & \multicolumn{2}{|c|}{$\begin{array}{l}\text { Levene's Test } \\
\text { for Equality } \\
\text { of Variances }\end{array}$} & \multicolumn{7}{|c|}{ t-test for Equality of Means } \\
\hline & & \multirow{2}{*}{$\begin{array}{c}\text { F } \\
\text { Lower }\end{array}$} & \multirow{2}{*}{$\begin{array}{l}\text { Sig. } \\
\text { Upper }\end{array}$} & \multirow{2}{*}{$\begin{array}{c}\mathbf{t} \\
\text { Lower }\end{array}$} & \multirow{2}{*}{$\begin{array}{c}\text { df } \\
\text { Upper }\end{array}$} & \multirow{2}{*}{$\begin{array}{c}\text { Sig. } \\
(2- \\
\text { tailed) }\end{array}$} & \multirow{2}{*}{$\begin{array}{c}\begin{array}{c}\text { Mean } \\
\text { Diff. }\end{array} \\
\text { Upper }\end{array}$} & \multirow{2}{*}{$\begin{array}{c}\text { Std. } \\
\text { Error } \\
\text { Diff. } \\
\text { Lower }\end{array}$} & \multicolumn{2}{|c|}{$\begin{array}{c}95 \% \\
\text { Confidence } \\
\text { Interval of the } \\
\text { Difference } \\
\end{array}$} \\
\hline & & & & & & & & & Upper & Lower \\
\hline \multirow[t]{2}{*}{$\begin{array}{l}\text { Mean32 } \\
\text { Items }\end{array}$} & $\begin{array}{l}\text { Equal } \\
\text { variances } \\
\text { assumed }\end{array}$ & .188 & .665 & -2.937 & 306 & .004 & -.19255 & .06557 & -.3215 & -.0635 \\
\hline & $\begin{array}{l}\text { Equal } \\
\text { variances } \\
\text { not } \\
\text { assumed }\end{array}$ & & & -3.064 & 172.55 & .003 & -.19255 & .06284 & -.3165 & -.0685 \\
\hline
\end{tabular}

The Group Statistics table indicates that equal variances can be assumed. From the relevant row in the Independent Samples Test table the Sig. (2-tailed) statistic is less than 0.05 which allows the conclusion that there is a statistically significant difference between the mean scores of the two groups in relation to what constitutes employer attractiveness. This supports the contention of hypothesis 1: there is a significant difference between graduating students and experienced employees in the degree to which employer attributes attract them to an employer. 
2. Key factors influencing the perceptions of employer attractiveness

Table 2 indicates the mean scores of each group in relation to each of the 32 items in the modified EmpAt scale.

Table 2: Mean scores of respondents on modified EmpAt scale

\begin{tabular}{|c|c|c|}
\hline & Graduating Students & MBA Students \\
\hline $\begin{array}{l}\text { Appreciation From } \\
\text { Management }\end{array}$ & 6.11 & 6.31 \\
\hline Fun Environment & 5.20 & 5.56 \\
\hline Future Opportunities & 6.38 & 6.15 \\
\hline Promotes Self Esteem & 6.26 & 6.39 \\
\hline Develops Confidence & 6.22 & 6.23 \\
\hline Gaining Career Experience & 6.48 & 6.36 \\
\hline $\begin{array}{l}\text { Good Relationship with } \\
\text { Superiors }\end{array}$ & 6.09 & 6.03 \\
\hline $\begin{array}{l}\text { Good Relationships with } \\
\text { Colleagues }\end{array}$ & 6.07 & 6.14 \\
\hline Supportive Colleagues & 5.87 & 5.85 \\
\hline Exciting Environment & 4.84 & 5.31 \\
\hline Innovative & 5.89 & 5.83 \\
\hline Values Creativity & 5.99 & 5.88 \\
\hline High Quality Products & 5.57 & 5.80 \\
\hline Innovative Products & 5.32 & 5.45 \\
\hline Good Promotion Opportunities & 5.92 & 5.93 \\
\hline Socially Responsible & 5.75 & 5.63 \\
\hline $\begin{array}{l}\text { Can Use University } \\
\text { Knowledge }\end{array}$ & 5.80 & 5.59 \\
\hline $\begin{array}{l}\text { Can Teach Others University } \\
\text { Knowledge }\end{array}$ & 5.24 & 5.33 \\
\hline Acceptance \& Belonging & 5.67 & 5.70 \\
\hline Customer-oriented & 5.23 & 5.26 \\
\hline Job Security & 6.23 & 6.22 \\
\hline Offers Range of Experience & 5.69 & 5.61 \\
\hline Happy Environment & 6.23 & 6.09 \\
\hline Above Average Salary & 6.00 & 6.00 \\
\hline $\begin{array}{l}\text { Attractive Compensation } \\
\text { Package }\end{array}$ & 5.93 & 6.03 \\
\hline Profitable Company & 5.41 & 5.46 \\
\hline Large Company & 4.64 & 4.84 \\
\hline Well Known Company & 4.57 & 4.55 \\
\hline Product or Service Type & 4.94 & 4.93 \\
\hline Quality Management & 5.86 & 5.89 \\
\hline Honest \& Fair & 5.85 & 5.82 \\
\hline Gives Personal Respect & 5.45 & 5.77 \\
\hline Valid N (listwise) & 221 & 87 \\
\hline
\end{tabular}


In terms of which factors are most and least related to employer attractiveness there is a strong similarity between the graduating students and the more experienced employees of the MBA group. These are summarized in Table 3.

Table 3: Most-preferred and least-preferred employer attributes (32 modified EmpAt scale items)

\begin{tabular}{|c|l|l|}
\hline & \multicolumn{1}{|c|}{ Graduating Students } & \multicolumn{1}{c|}{ MBA Students } \\
\hline $\begin{array}{c}\text { Most Preferred } \\
\text { Attributes } \\
\text { in descending order) }\end{array}$ & $\begin{array}{l}\text { Gaining experience to help } \\
\text { career* } \\
\text { Future opportunities* } \\
\text { Promotes self-esteem* } \\
\text { Job security* } \\
\text { Happy environment } \\
\text { Develops confidence* }\end{array}$ & $\begin{array}{l}\text { Promotes self-esteem* } \\
\text { Gaining career experience* } \\
\text { Appreciation from management } \\
\text { Develops confidence* } \\
\text { Job security* } \\
\text { Future opportunities* }\end{array}$ \\
\hline $\begin{array}{c}\text { Least Preferred } \\
\text { Attributes }\end{array}$ & $\begin{array}{l}\text { Well-known company* } \\
\text { Large company* } \\
\text { Exciting environment* } \\
\text { Product or service type* } \\
\text { Fun environment } \\
\text { Customer-oriented* }\end{array}$ & $\begin{array}{l}\text { Well-known company* } \\
\text { Large company* } \\
\text { Product or service type* } \\
\text { Customer-oriented* } \\
\text { Exciting environment* } \\
\text { Can teach others university } \\
\text { knowledge }\end{array}$ \\
\hline
\end{tabular}

- Item occurs for both groups

In both of the most preferred and least preferred attribute lists five of the six items are common to both the graduating students and the MBA students. The high correlation between the two groups is further indicated in Table 4.

Table 4: Correlations between means of employer attraction attributes

\begin{tabular}{|l|l|c|c|}
\hline \multirow{3}{*}{ Graduating } & $\begin{array}{l}\text { Pearson } \\
\text { Correlation }\end{array}$ & 1 & $.951^{* *}$ \\
\cline { 2 - 4 } & Sig. (2-tailed) & & .000 \\
\cline { 2 - 4 } & $\mathrm{N}$ & 32 & 32 \\
\hline \multirow{2}{*}{ MBA } & $\begin{array}{l}\text { Pearson } \\
\text { Correlation }\end{array}$ & $.951^{* *}$ & 1 \\
\cline { 2 - 4 } & Sig. (2-tailed) & .000 & \\
\cline { 2 - 4 } & $\mathrm{N}$ & 32 & 32 \\
\hline \multirow{2}{*}{$* *$ Correlation is significant at the 0.01 level (2-tailed). } \\
\hline
\end{tabular}

An examination of the greatest differences (.2 or higher) between the scores of the graduating students and the MBA students reveals the following (Table 5):

Table 5: Highest differences in mean scores

\begin{tabular}{|l|c|c|c|}
\hline \multicolumn{1}{|c|}{ Attribute } & $\begin{array}{c}\text { Graduating Students: } \\
\text { Mean Score }\end{array}$ & $\begin{array}{c}\text { MBA Students: } \\
\text { Mean Score }\end{array}$ & $\begin{array}{c}\text { Difference Between } \\
\text { Mean Scores }\end{array}$ \\
\hline Exciting Environment & 4.84 & 5.31 & +0.47 \\
\hline Fun Environment & 5.20 & 5.56 & +0.36 \\
\hline Gives Personal Respect & 5.45 & 5.77 & +0.32 \\
\hline High Quality Products & 5.57 & 5.80 & +0.23 \\
\hline
\end{tabular}




\begin{tabular}{|l|c|c|c|}
\hline $\begin{array}{l}\text { Appreciation from } \\
\text { Management }\end{array}$ & 6.11 & 6.31 & +0.20 \\
\hline Large Company & 4.64 & 4.84 & +0.20 \\
\hline $\begin{array}{l}\text { Can Use University } \\
\text { Knowledge }\end{array}$ & 5.80 & 5.59 & -0.21 \\
\hline Future Opportunities & 6.38 & 6.15 & -0.23 \\
\hline
\end{tabular}

The MBA students, the more experienced workers, differ from the graduating students most significantly in relation to social and personal aspects of the work environment, rather than in aspects of the actual employment task. While the undergraduates are focused largely on the job task-related attributes those already in employment indicate a greater awareness of the significance of the informal aspects of the work environment. At the same time, the undergraduates are understandably more enthusiastic to use their univ ersity acquired knowledge and concerned about future career opportunities. All in all the hypothesis 2: there is a significant difference between graduating students and experienced employees in the most- and leastpreferred attributes which attract them to an employer, was rejected.

\section{Dimensions of Employer Attractiveness}

From our earlier study we identified the main dimensions of employer attractiveness for the graduating students through a factor analysis as follows (Table 6):

Table 6: Summary of Component Variables

\begin{tabular}{|c|c|c|c|c|c|c|c|}
\hline $\begin{array}{c}\text { Factor } \\
1\end{array}$ & $\begin{array}{c}\text { Factor } \\
2\end{array}$ & $\begin{array}{c}\text { Factor } \\
3\end{array}$ & $\begin{array}{c}\text { Factor } \\
4\end{array}$ & $\begin{array}{c}\text { Factor } \\
5\end{array}$ & $\begin{array}{c}\text { Factor } \\
6\end{array}$ & $\begin{array}{c}\text { Factor } \\
7\end{array}$ & $\begin{array}{c}\text { Factor } \\
8\end{array}$ \\
\hline $\begin{array}{l}\text { Large } \\
\text { Company }\end{array}$ & $\begin{array}{l}\text { Above } \\
\text { Average } \\
\text { Salary }\end{array}$ & $\begin{array}{l}\text { Can Use } \\
\text { Univ. } \\
\text { Knowledge }\end{array}$ & $\begin{array}{l}\text { Happy } \\
\text { Environment }\end{array}$ & $\begin{array}{l}\text { Good } \\
\text { Relationships } \\
\text { with } \\
\text { Colleagues }\end{array}$ & $\begin{array}{l}\text { Develops } \\
\text { Confidence }\end{array}$ & Innovative & $\begin{array}{l}\text { Exciting } \\
\text { Environment }\end{array}$ \\
\hline $\begin{array}{l}\text { Well Known } \\
\text { Company }\end{array}$ & $\begin{array}{l}\text { Attractive } \\
\text { Compensation } \\
\text { Package }\end{array}$ & $\begin{array}{l}\text { Can Teach } \\
\text { Others } \\
\text { Univ. } \\
\text { Knowledge }\end{array}$ & $\begin{array}{l}\text { Appreciation } \\
\text { From } \\
\text { Management }\end{array}$ & $\begin{array}{l}\text { Good } \\
\text { Relationship } \\
\text { With } \\
\text { Superiors }\end{array}$ & $\begin{array}{l}\text { Promotes } \\
\text { Self } \\
\text { Esteem }\end{array}$ & $\begin{array}{l}\text { Values } \\
\text { Creativity }\end{array}$ & $\begin{array}{l}\text { Fun } \\
\text { Environment }\end{array}$ \\
\hline $\begin{array}{l}\text { Product or } \\
\text { Service } \\
\text { Type }\end{array}$ & Job Security & $\begin{array}{l}\text { Socially } \\
\text { Responsible }\end{array}$ & $\begin{array}{l}\text { Honest \& } \\
\text { Fair }\end{array}$ & $\begin{array}{l}\text { Supportive } \\
\text { Colleagues }\end{array}$ & $\begin{array}{l}\text { Gaining } \\
\text { Career } \\
\text { Experience }\end{array}$ & $\begin{array}{l}\text { Innovative } \\
\text { Products }\end{array}$ & $\begin{array}{l}\text { Gives } \\
\text { Personal } \\
\text { Respect }\end{array}$ \\
\hline $\begin{array}{l}\text { Profitable } \\
\text { Company }\end{array}$ & $\begin{array}{l}\text { Future } \\
\text { Opportunities }\end{array}$ & $\begin{array}{l}\text { Acceptance } \\
\& \\
\text { Belonging }\end{array}$ & $\begin{array}{l}\text { Customer- } \\
\text { oriented }\end{array}$ & & & $\begin{array}{l}\text { Offers } \\
\text { Range of } \\
\text { Experience }\end{array}$ & \\
\hline $\begin{array}{l}\text { High } \\
\text { Quality } \\
\text { Products }\end{array}$ & $\begin{array}{l}\text { Good } \\
\text { Promotion } \\
\text { Opportunities }\end{array}$ & & & & & & \\
\hline $\begin{array}{l}\text { Quality } \\
\text { Management }\end{array}$ & & & & & & & \\
\hline
\end{tabular}

A similar factor analysis was conducted on the data obtained from the MBA students. Table 7 presents the variance between the variables, from which a total of 10 factor dimensions were identified. As two dimensions contained only one factor they can be disregarded as having any definitive value. In both cases therefore, eight dimensions are relevant. 
Table 7: Factor analysis - MBA student survey

\begin{tabular}{|c|c|c|c|c|c|c|c|c|c|}
\hline \multirow[t]{2}{*}{$\begin{array}{l}\text { Comp- } \\
\text { onent }\end{array}$} & \multicolumn{3}{|c|}{ Initial Eigenvalues } & \multicolumn{3}{|c|}{$\begin{array}{l}\text { Extraction Sums of Squared } \\
\text { Loadings }\end{array}$} & \multicolumn{3}{|c|}{ Rotation Sums of Squared Loadings } \\
\hline & Total & $\begin{array}{c}\% \text { of } \\
\text { Variance }\end{array}$ & $\begin{array}{c}\text { Cumulative } \\
\%\end{array}$ & Total & $\begin{array}{c}\% \text { of } \\
\text { Variance }\end{array}$ & $\begin{array}{c}\text { Cumulative } \\
\%\end{array}$ & Total & $\begin{array}{c}\% \text { of } \\
\text { Variance }\end{array}$ & $\begin{array}{c}\text { Cumulative } \\
\%\end{array}$ \\
\hline 1 & 9.222 & 28.819 & 28.819 & 9.222 & 28.819 & 28.819 & 3.394 & 10.606 & 10.606 \\
\hline 2 & 2.730 & 8.532 & 37.352 & 2.730 & 8.532 & 37.352 & 3.050 & 9.532 & 20.138 \\
\hline 3 & 2.157 & 6.740 & 44.091 & 2.157 & 6.740 & 44.091 & 2.682 & 8.382 & 28.520 \\
\hline 4 & 1.986 & 6.207 & 50.298 & 1.986 & 6.207 & 50.298 & 2.675 & 8.359 & 36.879 \\
\hline 5 & 1.785 & 5.579 & 55.877 & 1.785 & 5.579 & 55.877 & 2.526 & 7.895 & 44.774 \\
\hline 6 & 1.356 & 4.237 & 60.114 & 1.356 & 4.237 & 60.114 & 2.244 & 7.012 & 51.786 \\
\hline 7 & 1.312 & 4.101 & 64.215 & 1.312 & 4.101 & 64.215 & 1.989 & 6.217 & 58.003 \\
\hline 8 & 1.131 & 3.533 & 67.748 & 1.131 & 3.533 & 67.748 & 1.977 & 6.177 & 64.180 \\
\hline 9 & 1.057 & 3.302 & 71.050 & 1.057 & 3.302 & 71.050 & 1.845 & 5.765 & 69.945 \\
\hline 10 & 1.007 & 3.147 & 74.197 & 1.007 & 3.147 & 74.197 & 1.360 & 4.251 & 74.197 \\
\hline 11 & .759 & 2.371 & 76.567 & & & & & & \\
\hline 12 & .678 & 2.117 & 78.685 & & & & & & \\
\hline 13 & .656 & 2.049 & 80.734 & & & & & & \\
\hline 14 & .620 & 1.938 & 82.672 & & & & & & \\
\hline 15 & .587 & 1.835 & 84.506 & & & & & & \\
\hline 16 & .580 & 1.812 & 86.319 & & & & & & \\
\hline 17 & .494 & 1.543 & 87.862 & & & & & & \\
\hline 18 & .474 & 1.481 & 89.343 & & & & & & \\
\hline 19 & .414 & 1.293 & 90.636 & & & & & & \\
\hline 20 & .393 & 1.227 & 91.863 & & & & & & \\
\hline 21 & .366 & 1.144 & 93.008 & & & & & & \\
\hline 22 & .343 & 1.072 & 94.079 & & & & & & \\
\hline 23 & .280 & .875 & 94.954 & & & & & & \\
\hline 24 & .269 & .840 & 95.794 & & & & & & \\
\hline 25 & .244 & .762 & 96.556 & & & & & & \\
\hline 26 & .221 & .692 & 97.248 & & & & & & \\
\hline 27 & .198 & .619 & 97.866 & & & & & & \\
\hline 28 & .184 & .574 & 98.441 & & & & & & \\
\hline 29 & .159 & .498 & 98.939 & & & & & & \\
\hline 30 & .149 & .465 & 99.404 & & & & & & \\
\hline 31 & .105 & .327 & 99.731 & & & & & & \\
\hline 32 & .086 & .269 & 100.000 & & & & & & \\
\hline
\end{tabular}

Extraction Method: Principal Component Analysis.

The dimensions from both the graduating students and the MBA students are summarized in Table 8. They have been tabulated so as to allow a comparison between the dimensions which most closely align with each other.

Table 8: Summary of Component Variables - Graduating Students and MBA Students

\begin{tabular}{|c|l|l|}
\hline Factor & \multicolumn{1}{|c|}{ Graduating Students } & \multicolumn{1}{c|}{ MBA Students } \\
\hline 1 & Large Company* & Large company* \\
& Well Known Company* & Well known company* \\
& $\begin{array}{l}\text { Product or Service Type* } \\
\text { Profitable Company* }\end{array}$ & Profitable company* \\
& Product or service type* \\
& Quagh Quality Products \\
& \\
& \multicolumn{2}{|l}{} \\
\hline
\end{tabular}




\begin{tabular}{|c|c|c|}
\hline 2 & $\begin{array}{l}\text { Above Average Salary* } \\
\text { Attractive Compensation } \\
\text { Package* } \\
\text { Job Security } \\
\text { Future Opportunities } \\
\text { Good Promotion } \\
\text { Opportunities }\end{array}$ & $\begin{array}{l}\text { Above average salary* } \\
\text { Attractive compensation } \\
\text { package* } \\
\text { Quality management }\end{array}$ \\
\hline 3 & $\begin{array}{l}\text { Can Use University. } \\
\text { Knowledge* } \\
\text { Can Teach Others Univ. } \\
\text { Knowledge* } \\
\text { Socially Responsible } \\
\text { Acceptance \& Belonging }\end{array}$ & $\begin{array}{l}\text { Can use university } \\
\text { knowledge* } \\
\text { Can teach others university } \\
\text { knowledge* } \\
\text { Values creativity } \\
\text { Customer-oriented }\end{array}$ \\
\hline 4 & $\begin{array}{l}\text { Happy Environment* } \\
\text { Appreciation From } \\
\text { Management } \\
\text { Honest \& Fair* } \\
\text { Customer-oriented }\end{array}$ & $\begin{array}{l}\text { Happy environment* } \\
\text { Honest and fair* } \\
\text { Acceptance and belonging } \\
\text { Gives personal respect }\end{array}$ \\
\hline 5 & $\begin{array}{l}\text { Good Relationships with } \\
\text { Colleagues* } \\
\text { Good Relationship With } \\
\text { Superiors* } \\
\text { Supportive Colleagues* }\end{array}$ & $\begin{array}{l}\text { Good relationships with } \\
\text { colleagues* } \\
\text { Good relationships with } \\
\text { superiors* } \\
\text { Supportive colleagues* } \\
\text { Gaining career experience } \\
\text { High quality products }\end{array}$ \\
\hline 6 & $\begin{array}{l}\text { Develops Confidence* } \\
\text { Promotes Self Esteem* } \\
\text { Gaining Career } \\
\text { Experience }\end{array}$ & $\begin{array}{l}\text { Develops confidence* } \\
\text { Promotes self-esteem* } \\
\text { Future opportunities } \\
\text { Appreciation from } \\
\text { management }\end{array}$ \\
\hline 7 & $\begin{array}{l}\text { Innovative } \\
\text { Values Creativity } \\
\text { Innovative Products* } \\
\text { Offers Range of } \\
\text { Experience }\end{array}$ & $\begin{array}{l}\text { Innovative products* } \\
\text { Good promotion } \\
\text { opportunities } \\
\text { Job security }\end{array}$ \\
\hline 8 & $\begin{array}{l}\text { Exciting Environment* } \\
\text { Fun Environment* } \\
\text { Gives Personal Respect }\end{array}$ & $\begin{array}{l}\text { Exciting environment* } \\
\text { Fun environment* }\end{array}$ \\
\hline 9 & & Innovative \\
\hline 10 & & Socially responsible \\
\hline
\end{tabular}

- Item occurs for both groups 
On the basis of this subjective structuring Table 8 shows that 18 of the 32 variables can be matched with a corresponding dimension between the two groups. In order to determine the statistical significance the mean for variables in each dimension was calculated separately for each group and analysed using the Independent Samples $t$ Test (Table 9).

Table 9: Independent Samples $t$-Test of graduating students and MBA student groups

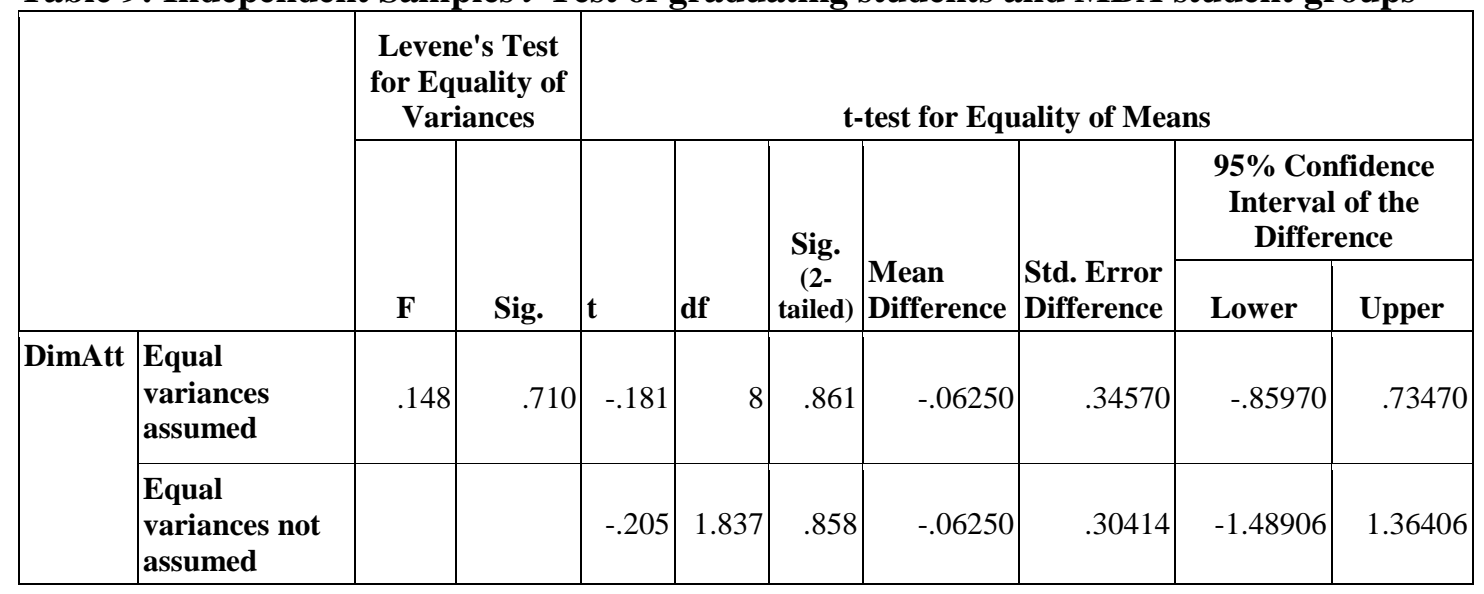

As the Sig. (2-tailed) is greater than .05 it can be concluded that there is no statistically significant difference between the two groups in terms of the dimensions of employer attractiveness. Hence the hypothesis 3: there is a significant difference between graduating students and experienced employees in the dimensions of attractiveness to a preferred employer, was not supported.

\section{Limitations of the Study}

The study focuses on those due to graduate or have graduated from universities. Given the lack of university places available in Sri Lanka this represents only a small percentage of the workforce and therefore not truly indicative of the majority of jobseekers and employees. In addition, all of the graduating student respondents were from the Business faculty of one university while the MBA students were from a range of academic disciplines. It could be argued that this gave greater breadth to the study but it also may indicate an inconsistency between the structure of both test groups.

The EmpAt test in its original form was devised specifically for undergraduate students with little or no work experience and may therefore may not be entirely appropriate for respondents with a more extensive employment background. The fact that it was administered without reference to any particular employing organizations may have resulted in the lack of a focus upon which the respondents, particularly the graduating student group, could relate their perceptions.

\section{Implications of the Findings}

The findings indicate a statistically significant difference between the mean scores of the graduating students and the MBA students as to what constitutes employer attractiveness, thereby supporting the contention of Hypothesis 1. Neither of the other two hypotheses is, however, supported by the analysis of the research data. 
While the two groups appear to rate the 32 scale items to different degrees they nonetheless both have very similar perceptions of which employer attributes attract and detract, with an emphasis on personal and career development opportunities and job security rather than structural organizational characteristics such as company size, reputation, product or service and customer-orientation. In contrast, Australian students saw compensation and the social aspects of the work environment as highly attractive while innovativeness, social responsibility and customer-orientation were of lowest appeal (Berthon et al, 2005), although they were surveyed on a lesser number of items than the Sri Lankan students.

The greatest differences between the perceptions of the two Sri Lankan cohorts related to the social and personal aspects of the work environment, principally an exciting and fun environment and personal respect, which were considered to be of greater importance to the experienced workers than the undergraduates who gave greater emphasis to using their university knowledge and future career opportunities.

Although there was some variation between the two groups in the dimensions of employer attractiveness there was also considerable commonality, an observation supported by statistical analysis.

The results of this research should be of considerable value to HRM managers in Sri Lanka in respect to gaining awareness of the following:

1. The employer attributes most preferred by job seekers relate to personal growth and career development opportunities and job security.

2. The least preferred employer attributes relate to organizational characteristics such as size, being well-known, its product or service and the nature of customer-orientation.

3. There is a strong similarity between Sri Lankan graduating students and experienced employees in their perceptions of attractive employer attributes although there is some difference between the two groups in the degree of importance attached.

\section{Conclusion}

Understanding the factors which contribute to employer attractiveness is essential if organisations are to develop an employer brand that is effective in the recruitment and retention of employees.

Essentially this study has shown that there is little difference between Sri Lankan graduating students and more experienced workers in their perception of the attributes that would attract them to an employer. This tends to be in contrast to what the available literature suggests in relation to the type of employer attractiveness attributes and dimensions. However we have found that there is a significant difference between the degree to which the groups rate these attributes.

Individual differences will play a part in variations between perceptions but there is a definite commonality between the less and more experienced employees. This may be linked to social and cultural factors, the nature of the local employment market or the local organizational environment. 
It is anticipated that the application of the findings of this study can be of considerable benefit to company policy makers and HRM professionals in the development of an employer brand and in the recruitment and retention of employees particularly at the professional level.

\section{References}

Ambler, T. and Barrow, S. (1996), "The employer brand", The Journal of Brand Management, Vol.4, pp. 185-206.

Arachchige, B. and Robertson, A. (2011), "Business student perceptions of a preferred employer: A study identifying determinants of employer branding", IUP Journal of Brand Management, Vol. 8, No. 3, pp. 25-46.

Backhaus, K. and Tikoo, S. (2004), "Conceptualising and researching employer branding", Career Development International, Vol.4, No. 5, pp. 501-17.

Berthon, P., Ewing, M. and Hah, L.L. (2005), "Captivating company: dimensions of attractiveness in employer branding", International Journal of Advertising, Vol.24, No.2, pp.151-172.

Cable, D.M. and Graham, M. (2000), "The determinants of organizational reputation: a job search perspective" Journal of Organisational Behaviour, Vol.21, No.8, pp. 929-947.

Carrington, L. (2007), "Designs on the dotted line", People Management, Vol. 13, No. 21, pp. $36-39$.

Chambers, E.G., Foulon, M. Handfield-Jones, H., Hankin, S.M. and Michaels, E.G. (1998), "The war for talent", McKinsey Quarterly, No. 3, pp. 44-57.

Collins, C.J. and Stevens, C.K. (2002), "The relationship between early recruitmentrelated activities and the application decisions of new labour-market entrants: A brand equity approach to recruitment", Journal of Applied Psychology, Vol. 87, No. 6, pp. 1121-1133.

Lievens, F. (2007), "Employer branding in the Belgian army: The importance of instrumental and symbolic beliefs for potential applicants, actual applicants and military employees", Human Resource Management, Vol.46, No.1, pp. 51-69.

Lloyd, S. (2002), "Branding from the inside out", BRW, Vol. 24, No.10, pp. 23-31.

Maxwell, R. and Knox, S. (2009), "Motivating employees to 'live the brand': a comparative case study of employer brand attractiveness within the firm", Journal of Marketing Management, Vol. 25, No. 9-10, pp. 893-907.

Minchington, B. (2009), "Help wanted!", www.marketingmix.co.za/pebble.asp?r, accessed 20 December, 2010.

Rosethorn, H. (ed) (2009), The Employer Brand, Gower Publishing, Surrey, UK.

Roy, K.S. (2008), "Identifying the dimensions of attractiveness of an employer brand in the Indian context", South Asian Journal of Management, Vol. 15, No. 4, pp. 110-130.

Rynes, S., Heneman, H. and Schwab, D. (1980), "Individual reactions to organizational recruiting: A review”, Personnel Psychology, No. 33, pp. 529542.

Sheppard, G. (2010), "An industry in flux", Personnel Today, 2010 Guide to Employer Branding Sup. pp. 5-8.

Taylor, A. (2005), "Global growth to fall unless people work longer", Financial Times (London), 11 October, p. 12. 
Tweedy, R. (2011), "A new weapon in the "war for talent'”, Recruiter, 9 March, www.recruiter.co.uk, p. 24, accessed on 6 June, 2011.

Van Mossevelde, C. (2010), "Employer Branding: Five Reasons why it Matters and Five Steps to Action", Employer Branding Today,

http://www.employerbrandingtoday.com/employ, accessed on 23 December, 2010.

Wells, W. (1993), "Discovery-oriented consumer research", Journal of Consumer Research, Vol. 19, pp. 489-504. 